Copyright (C) 2016 by Academic Publishing House Researcher

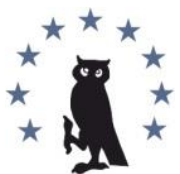

Published in the Russian Federation

Biogeosystem Technique

Has been issued since 2014 .

ISSN: 2409-3386

E-ISSN: $2413-7316$

Vol. 7, Is. 1, pp. 49-64, 2016

DOI: 10.13187/bgt.2016.7.49

www.ejournal19.com

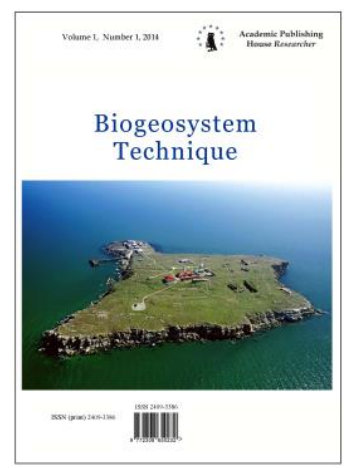

UDC 631,485

\title{
Duration Estimating Spending Soil under Active Development of Erosion Processes
}

\author{
1 Fedor N. Lisetskii \\ 2 Aleksandr N. Muntian \\ 3 Ksenija V. Zholumskaya
}

1 Belgorod State National Research University, Belgorod, Russia

308015 Belgorod, st. Victory, 85

2 Republican Scientific-Research Institute of Environment and Natural Resources, Bendery,

Moldova

1 Doctor of Geographical Sciences, Professor

E-mail: liset@bsu.edu.ru

2 Leading Researcher

E-mail: piter504@mail.ru

3 E-mail: zholumskaya@list.ru

\begin{abstract}
Preconditions of formation of soil conservation farming systems and prospects of irrigation reclamation development in the context of active manifestations of water erosion (for example, strongly dissected the central part of the Republic of Moldova) were investigated. It was found that over the past 20 years due to the intensification of agricultural production, the use of heavy equipment and the use of irrigation washability value of land increased by 1.5-2 times. It is shown that within the subsystem slope position-dynamic type agrolandscapes units have views of the landscape rather narrow bands. Their boundaries can be justified not only by the methods of landscape mapping, but also with the help of an integrated indicator of the potential duration of soil consumption, which includes stock assessment of soil resources and resource velocity forming and soil-destroying processes. This approach is complemented by the use of a series of microclimatic irregularities card (first of all, heat and moisture) with quantitative gradation in the legend, and executed with the help of geographic information technologies allows for typing agroecological land and determine the most rational location for eco-restoration measures. As a result, the integrated application of biogeosystem-technology methods, adaptive-landscape approaches to land management in the face of strong manifestation of erosion there are new opportunities for controlling soil expenditure within the boundaries of landscape strips as the operating units contour-reclamation organization of agricultural landscapes to ensure the conditions of ecological rehabilitation of degraded land in the conservation mode, or annealing, as well as the creation of conditions for the conservation of biological diversity.
\end{abstract}

Keywords: soil erosion; soil formation; land irrigation; erosion control reclamation. 


\section{Введение}

Общепринятая практика противоэрозионного проектирования структуры агроландшафтов основана на сопоставлении расчетных величин смыва почв с допустимыми потерями, которые часто определяют на основе скорости формирования гумусового горизонта почв. При таком (оценочно-процессном) подходе остается в стороне оценка почвенного ресурса, дискретно распределенного в пространстве из-за многообразия комбинаций почвенно-формирующих и почвенно-деградационных процессов. Поэтому в целях выработки сценариев дальнейшего использования почвенно-земельных ресурсов, обоснования границ технологических групп земель при землеустроительном проектировании и расчета прогнозной оценки потенциальной длительности расходования почвы при постоянной среднемноголетней величине смыва необходима разработка и апробация комплексных показателей, которые интегрируют информацию о запасах почвенных ресурсов и скоростях ресурсоформирующих и почворазрушающих процессов.

Исследуемая территория представляет собой полигон площадью около $1900 \mathrm{KM}^{2}$, расположенный в центральной части Республики Молдова. С севера полигон ограничен рекой Бык, с юга и востока - реками Ботна и Днестр соответственно. Западная граница пролегает по линии, проведенной между истоком реки Ботны и средним течением реки Бык. Регион входит в состав Нижнебыковской равнины и вблизи истоков Ботны вдается в Центрально-Молдавскую возвышенность [1]. Средняя абсолютная высота составляет 125 м, у довольно изолированных плакоров отметки высот колеблются от 200 до 260 м, но отдельные останцы возвышаются до 300 м, максимальная высота в пределах региона 335 м (рис. 1).

Наибольшее распространение получил овражно-балочный тип рельефа, формирование которого началось в верхнем плиоцене [2]. Этапы развития эрозионноденудационного рельефа зафиксированы в виде надпойменных террас, число которых для рек Ботна и Бык по разным источникам $[2,3]$ варьирует от 4-5 до 8.

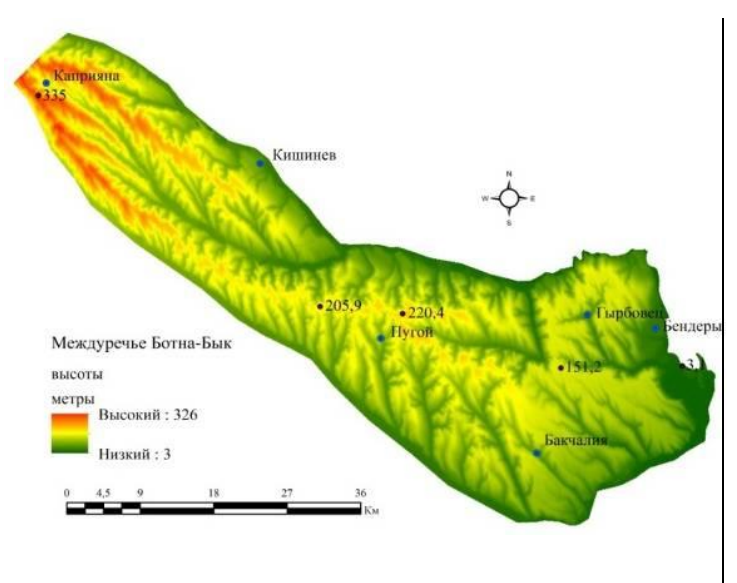

Рuc. 1. Орографические особенности междуречья Ботна-Бык

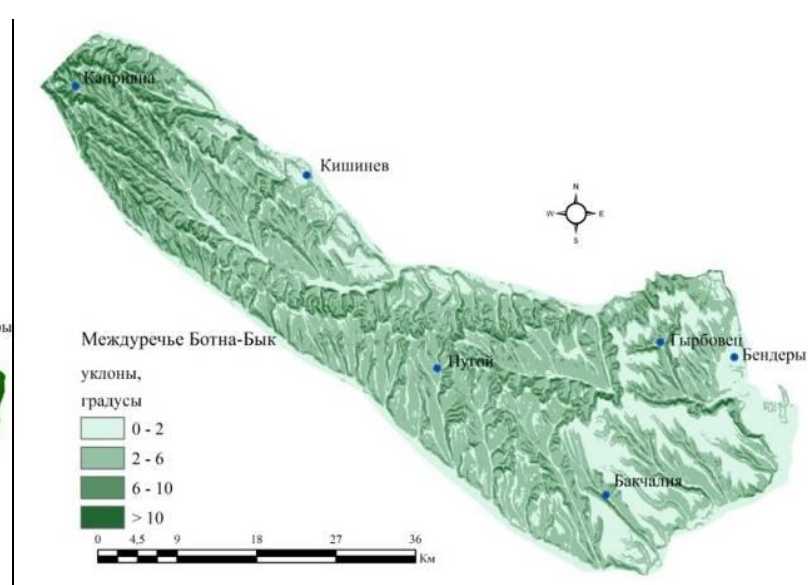

Рuc. 2. Распределение уклонов на территории междуречья Ботна-Бык

Рассматриваемый участок в пределах Нижнебыковской равнины входит в Пугойский (Быковский) геоморфологический район, в пределах которого выделяют [4] долиннотеррасовый генетический тип аккумулятивного рельефа, в том числе голоценовую пойму и неоплейстоценовые террасы, а также долинно-террасовый генетический тип денудационного рельефа.

По причине колебательного характера тектонических движений глубинная эрозия неоднократно сменялась аккумуляцией, что привело к террасированию долин. В долине реки Днестр насчитывается более 10 террас. На межбалочных пространствах в виде изолированных плато представлен наиболее древний уровень - аллювиальная позднеплиоценовая поверхность выравнивания. В целом территория имеет высотные отметки на уровне поверхности (раннечетвертичной) террасы и ниже. Это позволяет утверждать, что в четвертичный период междуречье неоднократно затоплялось речными 
разливами и перекрывалось новыми осадками, преимущественно субаквального происхождения. Средние и нижние (начиная с надпойменной) террасы Днестра, в основном, сложены лессовидными суглинками или лессами. Эти отложения охватывают также водораздельные пространства и террасы притоков Днестра.

По мере накопления лессовидных пород шел процесс их разрушения, смещения по склонам и вторичного отложения на склонах долин и балок в виде делювиальных лессовидных суглинков. Мощность их на нижних частях склонов достигает 10-20 м, уменьшаясь к верхней бровке до $1 \mathrm{M}$.

Среди современных факторов развития водной эрозии почв одним из ключевых является сложный рельеф территории (рис. 1). Глубина вертикального расчленения достигает 100-200 м, что согласно [5] способствует сильному и очень сильному проявлению эрозии. Установлено [6], что густота овражной сети и скорость роста оврагов именно в этих геоморфологических районах наибольшие. Распределение территории по уклонам (до $2^{\circ}-$ $29 \%$ площади, 2-6 $-50 \%, 6-10^{\circ}-18 \%$, больше $\left.10^{\circ}-3 \%\right)$ показывает, что значительные площади заняты пологими (до $6^{\circ}$ ) склонами, но немало и покатых склонов (рис. 2).

Среди почвообразующих пород доминируют тяжелые лессовидные суглинки (67\%). Почвенный покров (рис. 3) почти на 90\% представлен подтипами черноземов с территориальным преобладанием обыкновенных и карбонатных (вместе $-56,2 \%$ площади). Но на отрогах Центральной Молдавской возвышенности распространены также серые лесные и бурые лесные почвы.

Карбонатные черноземы характеризуются наличием карбонатов в поверхностном слое, щелочной реакцией по всему профилю, повышенным известковым потенциалом, заметной оглиненностью профиля, незначительной гумусированностью при довольно большой мощности гумусового горизонта. Обыкновенные черноземы отличаются от карбонатных лучшей оструктуренностью. С глубины 50-60 см различия между обыкновенными и карбонатными черноземами по морфологии, вещественному составу и свойствам сглаживаются. Различия между этими двумя подтипами черноземов реализуются и в такой интегральной характеристике как противоэрозионная стойкость почв. Оценка влияния генетического типа почв на процессы эрозии показала, что в зональном ряду почв Молдовы черноземы карбонатные характеризуются величиной относительного смыва почвы 1,5, если смыв на черноземах обыкновенных и типичных принять за 1.

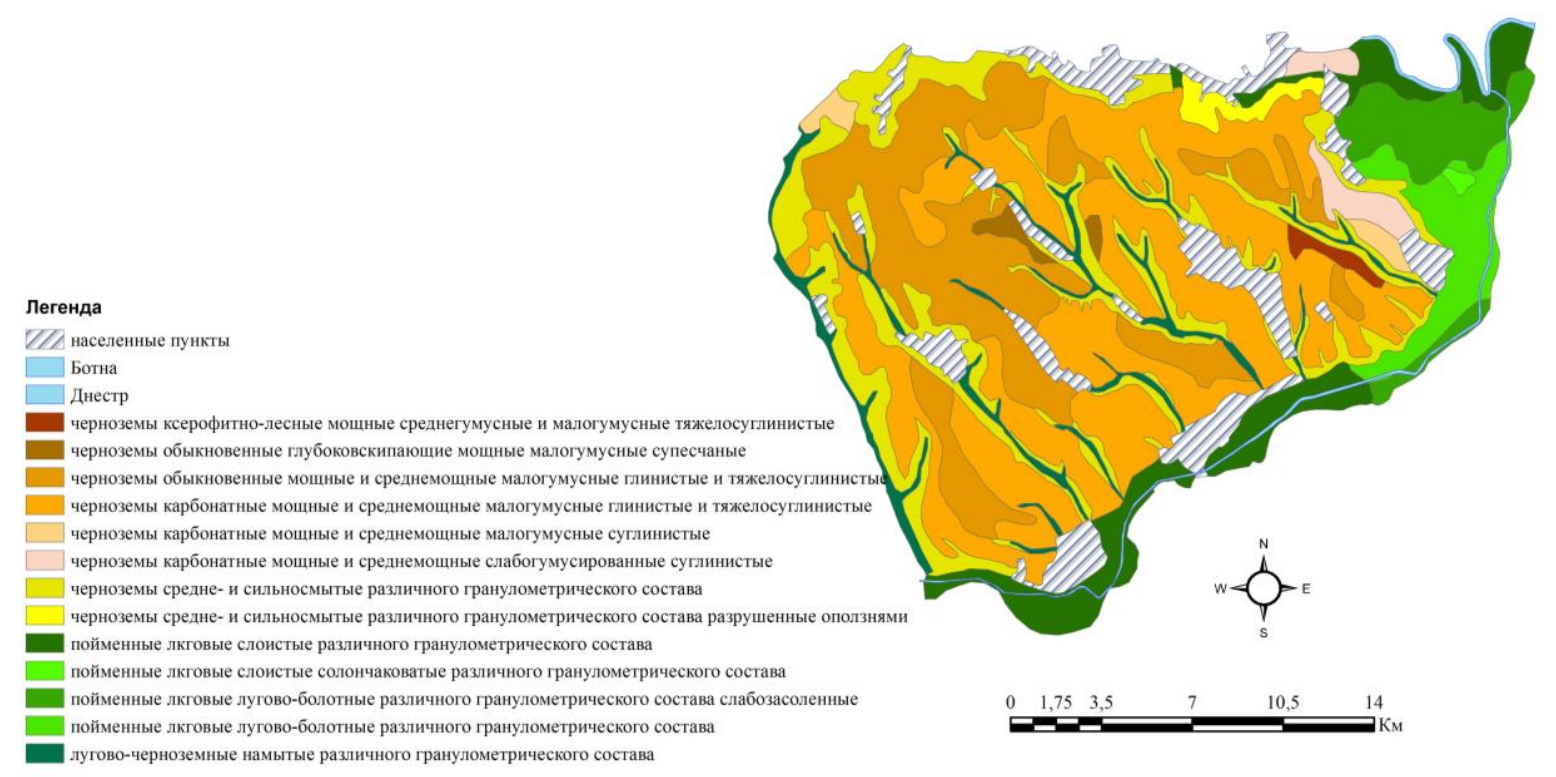

Puc. 3. Распределение почв по территории междуречья Ботна-Бык

Особенности геоморфологического строения территории республики (чередование низменных всхолмленных равнин с возвышенностями, быстрое изменение высот на 
сравнительно коротких линейных расстояниях и др.) в значительной мере осложняют широтную зональность почвенного покрова. В итоге, четко выражена высотная дифференциация почв. На склонах Молдовы среди морфологических единиц ландшафта наиболее репрезентативной является единица ранга ландшафтной полосы. Это природный территориальный комплекс, состоящий из закономерного сочетания морфологически однородных урочищ в пределах одного геоморфологического комплекса и одинаковых условий макроэкопозиции. По сути, каждая ландшафтная полоса отражает определенный гипсометрический уровень развития эрозионных процессов. Как правило, на одних и тех же материнских породах, но в различных условиях рельефа и при разных характеристиках стока формируется определенная последовательность почвенных разновидностей - катена, катенарный комплекс. Как на водораздельных пространствах с большими абсолютными высотами по сравнению с более низкими водоразделами, так и на водоразделах по сравнению со склонами, длительность почвообразования была более значительной, что нашло отражение и во многих параметрах почв. В пределах одного склона в результате преимущественного развития процессов смыва формируется однофакторная почвенная комбинация - сочетания (вариации) почв разной степени смытости.

Факторы развития водно-эрозионных процессов, включая высокую степень земледельческого освоения (57 \% пашни), привели к тому, что эродированные черноземы всех категорий занимают более 30 \% территории (рис. 3), и, хотя преобладают слабосмытые их разновидности (более 16 \%), но почти такая же площадь приходится на почвы более высоких степеней эродированности, а также на земли, сильно пораженные оврагами [7]. Современное состояние почвенного покрова в бассейне Днестра оценивается как неудовлетворительное приблизительно на 35 \% площадей, а как критическое - на 5 \% [8].

Другим, не менее важным, фактором эрозии является климат. Особенности климатических условий во многом определяют направленность и темпы развития эрозионных процессов. При этом они не одинаково протекают как по сезонам года, так и на отдельных территориях. Район исследования относится к зоне недостаточного увлажнения. Такой неблагоприятный режим выпадения осадков способствует развитию, как эрозионных процессов, так и почвенной засухи.

Средние годовые суммы осадков региона варьируют в пределах 489-533 мм, причем из них около 80 \% приходится на период с температурами воздуха выше $10^{\circ}$. В весенне-летний период большая часть осадков выпадает в виде ливней, наблюдаемый суточный максимум по метеостанции «Кишинев» на 8 июля 1948 г. составил 218 мм [9]. В целом условия увлажнения, особенно в экстремальные годы, довольно жесткие и могут изменяться более чем в 2 раза (от 316 мм в засушливые годы до 853 мм - во влажные).

В годы с обильными ливневыми осадками создается потенциальная опасность возникновения поверхностного смыва, а в годы с малым количеством осадков возрастает опасность сильных засух. Как правило, период максимального количества осадков совпадает с периодом наиболее высоких температур, что вызывает большие потери на испарение, которое часто усиливается низкой относительной влажностью воздуха. Если зимой относительная влажность составляет 60-90 \%, то летом она уменьшается до 50-60 \%. Вероятность засухи в теплый период в среднем составляет 30-35 \%.

В качестве характеристики эрозионной опасности климата в связи с неравномерным распределением осадков внутри года может быть использован плювиометрический коэффициент В.В. Сластихина [10], который определяется по следующей формуле:

$$
\mathrm{P}=\mathrm{K} \frac{\mathrm{m}}{\mathrm{M}}
$$

где $\mathrm{m}$ - среднемесячные осадки, в мм; M - среднегодовые осадки, в мм; К - показатель продолжительности расчетного периода.

Наивысшие значения плювиометрического коэффициента (> 1) для ряда пунктов Молдавии соответствуют периоду с мая по август. В этот период, который условно назван «эрозионно опасным», наиболее отчетливо наблюдается проявление эрозионных процессов. Для зимних месяцев значения плювиометрических коэффициентов в 2 раза меньше, чем для июня. Попутно отметим, что месячные суммы осадков дают лишь самое общее представление об эрозионной опасности территории. Поэтому плювиометрический 
коэффициент не отражает количественной стороны влияния осадков на эрозию и может быть использован лишь для общей характеристики на начальных этапах исследований.

Огромное влияние на формирование поверхностного стока и смыва оказывает интенсивность и характер выпадения осадков. Наиболее опасны в эрозионном отношении ливни (дожди с интенсивностью более о,05 мм/мин). Для ливневых осадков характерна пятнистость, наличие ливневых зон и зон слабых осадков со скачкообразным переходом от одних к другим, а также существенное снижение интенсивности с увеличением продолжительности. Средняя интенсивность особо обильных дождей сравнительно невелика, поскольку ливни часто чередуются со слабыми дождями. Наиболее часты ливни со средними интенсивностями за ливень равными о,1-0,5 мм/мин. Самые большие величины интенсивности достигают о,6-1 мм/мин.

Атмосферные жидкие осадки разной интенсивности в вегетационный период разрушают поверхностный слой почвы в различной степени. Обложные дожди, у которых средний диаметр капель не более 1 мм, незначительно воздействуют на него: масса перемещения частиц почвы при таких дождях не превышает 9,8 т/га, тогда как при ливневых осадках масса частиц достигает 97 т/га [11].

Продолжительность ливневой части, в течение которой осуществляется интенсивный поверхностный сток и смыв почвы, колеблется от о,6 до 1,6 часа. Некоторые ливневые дожди имеют эрозионную опасность большую, чем все дожди одного года и даже нескольких лет. К таким ливням относится дождь продолжительностью 3,5 часа, максимальной интенсивностью 2,58 мм/мин, а средней - 0,26 мм/мин. (Кишинев, 29.06.1964 г.). Максимальная интенсивность (10,7 мм/мин) зарегистрирована во время ливня, выпавшего 20 июня 1959 года в с. Валя Сатулуй.

В годовом ходе интенсивности осадков минимум наблюдается в январе, максимум почти по всей территории приходится на июнь. В отдельные годы, как минимум, так и максимум осадков могут быть сдвинуты на другие месяцы.

По данным метеостанции «Кишинев» максимальное количество осадков приходится на июнь только в 33 \% лет, на июль - в 22 \% лет, а в остальные годы приходится на разные месяцы года. Месячный максимум осадков колеблется на территории в пределах 55-85 мм, а месячный минимум - 15-30 мм. Средняя годовая амплитуда осадков колеблется от 35 до 55 MM.

Изменчивость сумм осадков в многолетнем режиме очень велика. В отдельные годы количество осадков может отклониться от среднего многолетнего значения на $\pm 200-300$ мм и более. В 30-40 \% периода наблюдения с 1891 по 2013 гг., отклонения от годовой суммы осадков превышают 100 мм.

Таким образом, осадки, выпадающие на территории Молдовы, имеют различный характер внутригодового распределения. В летнее время осадки выпадают преимущественно в виде ливней. Ливни летом выпадают в среднем 1-2 раза в месяц, что является мощным фактором развития эрозии. Осенью большинство дождей имеют обложной характер. В среднем за год выпадает 62 \% жидких, 11 \% смешанных и 7 \% твердых осадков.

Благоприятные условия тепло- и влагообеспеченности междуречья Ботна-Бык определяют довольно высокие значения энергетического потенциала почвообразования (Q (по Волобуеву)): на большей части территории величина Q находится в диапазоне от 1120 до 1160 МДж/( ${ }^{2} \cdot$ год) [12]. Однако на начало XXI века в регионе отмечается преобладание антициклонального типа погоды, которое отражается в уменьшении годового количества осадков, росте температуры воздуха, уменьшении годовой средней скорости ветра, уменьшении количества пасмурных дней, росте средней годовой амплитуды температуры воздуха [13].

Посредством динамического моделирования на базе имитационной компьютерной системы к 2021-2050 году, в рамках стабилизационной проекции климата (RCP 4.5), на летний период спрогнозирован рост средней температуры воздуха на $1,7{ }^{\circ} \mathrm{C}$, снижение суммарного количества осадков на 32 мм, коэффициента увлажнения за вегетационный период с о,69 до 0,57 [8]. 
Следует отметить, что для летних месяцев ожидается [14] 20-30 \%-ное уменьшение частоты суточных осадков при 5-10 \%-ном усилении их интенсивности. Вышеперечисленные тенденции ожидаемо приведут к аридизации климата и повышению эрозионной опасности региона.

Сложившиеся климатические условия в совокупности с ожидаемыми изменениями климата обусловили рассмотрение вопроса о развитии искусственного орошения. По данным Земельного Кадастра и Бюро Национальной статистики Молдовы пригодные для полива земли составляют 225 тыс. га, или 11,2 \% земель сельскохозяйственного назначения [8]. Однако, согласно данным региональных исследований $[15,16]$, орошение, как традиционное, так и капельное способствует деградации структурного состава почвы. Возрастают пептизация глинистых частиц, объемная масса и уплотненность почвы и снижаются водопрочность агрегатов, аэрация почвы, водопроницаемость почвы.

Отдельное внимание при орошении должно уделяться качеству воды, ввиду того что в условиях дефицита пресной речной воды орошение подземными водами любой степени минерализации со временем приводит, согласно исследованиям [17], к геохимической трансформации почв, выраженной в накоплении водорастворимых солей в почве. Таким образом, развитие систем орошения региона должно происходить в рамках внутрипочвенной импульсной континуально-дискретной парадигмы ирригации, позволяющей согласно исследованиям $[18,19]$, минимизировать трансформацию почв в результате орошения и обеспечить долговременное сохранение исходных геосистем орошаемых почв, ландшафтов и прилегающих территорий.

Имеющийся агропотенциал изученной территории, и текущая краткосрочная динамика климата позволяют предложить оптимистичный сценарий регионального развития на ближайшее время. Но непременным условием реализуемости такой стратегии является внедрение эффективных почвозащитных адаптивных систем земледелия. Кроме стандартных ингредиентов систем земледелия, ввиду критически большой интенсивности расходования почвы в условиях активного развития эрозионных процессов на ЮжноМолдавской холмисто-увалистой равнине, приближения почвообразующих пород к дневной поверхности, особенно с учетом того, что это явление дифференцировано в пространстве, следует ориентироваться на принципиально новые возможности синтеза агропочв, которые дает биогеосистемотехника [20].

Наряду с известной отечественной разработкой - щелеванием (по возвращении термина из-за рубежа в СССР, затем в РФ, получило распространение более позднее заимствование - чизелевание, от слова chisel - долото) для увеличения глубины корнеобитаемого слоя, следует ориентироваться также на новую отечественную разработку внутрипочвенное роторное фрезерование почвы. Оно обеспечивает наращивание почвы, долгосрочную направленность ее устойчивой агроэволюции, длительный агрономический и ландшафтно-экологический эффект [21]. Также возможно более эффективное, чем это обеспечивают стандартные технологии, размещение мелиорантов, структурообразователей, отходов во внутренних слоях почвы в процессе ее обработки [22].

Климатические условия юга Восточно-Европейской равнины обусловливают необходимость развития орошения. Условием реализации оптимистической стратегии является такое развитие ирригации, при котором будет заложен отказ от стандартной гравитационной фронтальной парадигмы ирригации [23, 24]. Она ведет к избыточному увлажнению, что опасно при высокой степени расчленения земельного фонда. Разработанные в 60-х годах XX века в ССCP [25] капельное, капельное внутрипочвенное орошение имеют дополнительное ограничение - значительную неравномерность давления вдоль капельной линии и как следствие - разную интенсивность подачи воды через отдельные капельницы и неравномерность полива [26]. Стандартные способы ирригации ведут к опасным почвенным [27, 28], ландшафтным, бассейновым, гидрологическим [29, 30], геохимическим, климатическим последствиям по всему миру: США [31], Индия, Китай и другие страны.

В свете вышесказанного, в условиях широкого развития эрозионно опасного рельефа, специфики почвенно-климатических условий предъявляются особые требования к эффективности противоэрозионных комплексов в Приднестровье как при организации 
территории в ходе землеустроительных действий, так и при проектировании оросительных систем. Таким образом, имеющийся агропотенциал территории и направленные изменения климата определяют необходимость внедрения эффективных почвозащитных адаптивных систем земледелия.

\section{Методика}

В пределах склоновой подсистемы агроландшафта единицы позиционнодинамического типа ландшафтной дифференциации выделяют таким образом, чтобы в их пределах интенсивность современных природных процессов была близкой и однотипной по динамическим показателям. Границы при позиционно-динамической структуризации ландшафта проводят в местах наибольших градиентов горизонтальных потоков - по каркасным линиям рельефа (водораздельной линии, тальвегу, бровке, подошве склона, линиям его перегибов). Территориальные единицы этого типа структуры часто имеют форму полос, почему и были названы Г.И. Швебсом [32] ландшафтными полосами, хотя в некоторых случаях они принимают изометрическую или кольцевую форму. В пределах одной ландшафтной полосы горизонтальные потоки, включая сток воды и наносов, однонаправлены и во всех точках имеют одинаковые градиенты.

Границы ландшафтных полос можно обосновать не только методами ландшафтного картографирования, но и при помощи комплексных показателей, которые включают оценки запасов почвенных ресурсов и скоростей ресурсоформирующих и почворазрушающих процессов. Предлагается использовать показатель потенциальной длительности расходования почвы при постоянной среднемноголетней величине смыва ( $T$, годы), который рассчитывается по формуле:

$$
T=\frac{10 \gamma\left(H_{И C X}-H_{O \Pi T}\right)}{V_{\ni}-V_{\Pi}},
$$

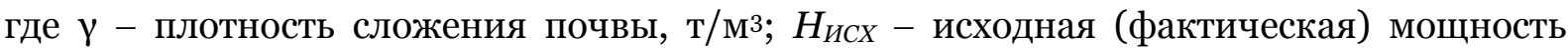

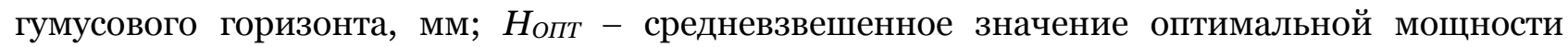
гумусового горизонта, учитывающее состав сельскохозяйственных культур в севообороте, мм (определяется по опытным данным либо может быть рассчитано по зависимости, отражающей изменение урожая 15 основных сельскохозяйственных культур от мощности гумусового горизонта [33]); $V_{\ni}$ - среднегодовой модуль потенциального смыва почвы, т/га; $V_{\Pi}$ - средние многолетние скорости почвообразования, т/га.

При сложившейся специализации растениеводства структуру посевов, оценку почвозащитной способности сельскохозяйственных культур (для последующей оценки их

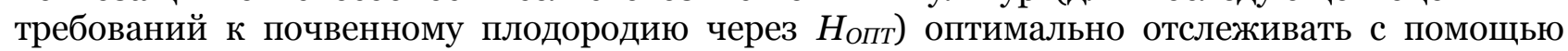
средств дистанционного зондирования Земли, а результаты структурировать в специализированной базе данных [34].

В отличие от часто практикуемого в противоэрозионном проектировании подхода, использующего прямое сопоставление интенсивности смыва (или выдувания) почвы со скоростью почвообразовательного процесса, расчетная формула комплексного показателя потенциальной длительности расходования почвы по формуле (1) относится к особой группе методик, которые включают помимо скоростей ресурсоформирующих и почворазрушающих процессов также оценку запасов почвенных ресурсов.

Потенциальный смыв почвы оценивали по формуле RUSLE [35]:

$$
\mathrm{A}=\mathrm{R} \times \mathrm{K} \times \mathrm{L} \times \mathrm{S} \times \mathrm{C} \times \mathrm{P}
$$

где A - среднее расчетное количество теряемой почвы в год на единицу площади т/га в год; R - коэффициент эродирующей способности осадков; $\mathrm{K}$ - коэффициент эродируемости почвы; L - коэффициент длины; S - коэффициент уклона; C - коэффициент растительного покрова и севооборотов; $\mathrm{P}$ - коэффициент охраны почв.

\section{Результаты и обсуждение}

Ранее [24] по датированным почвам Молдовы выполнена оценка среднемноголетних скоростей почвообразования и установлены различия почвообразовательного потенциала в лесостепной и степной частях Днестровско-Прутского междуречья. В первые зооо лет 
черноземы южно-степной подзоны имеют наибольшие скорости формирования гумусового горизонта (0,15-0,18 мм/год) и быстрее, чем другие подтипы, достигают его равновесной мощности, что подтверждает мнение [36] о том, что карбонатные черноземы являются почвой, которая среди других подтипов черноземов обладает наибольшими скоростями воспроизводства. Опираясь на результаты расчетов по моделям формирования гумусового горизонта черноземов Молдовы, определен [37] по оценке максимальных скоростей почвообразования следующий убывающий ряд: черноземы южно-степной подзоны $($ до $0,18 \mathrm{mм} /$ год) $\rightarrow$ черноземы северо-степной подзоны (до 0,14 мм/год) $\rightarrow$ черноземы Северо-Молдавской лесостепной провинции (до о,о9 мм/год).

Показатель потенциальной длительности расходования почвы, рассчитанный с включением в формулу (2) среднегодового модуля потенциального ливневого смыва почвы по модели RUSLE (формула 3), апробирован для условий расчлененных ландшафтов междуречья Ботна-Бык. На основе модели RUSLE дана оценка эрозионной силы осадков изучаемой территории (рис. 4), эрозионной устойчивости почв (рис. 5) и значения рельефной функции (рис. 6).

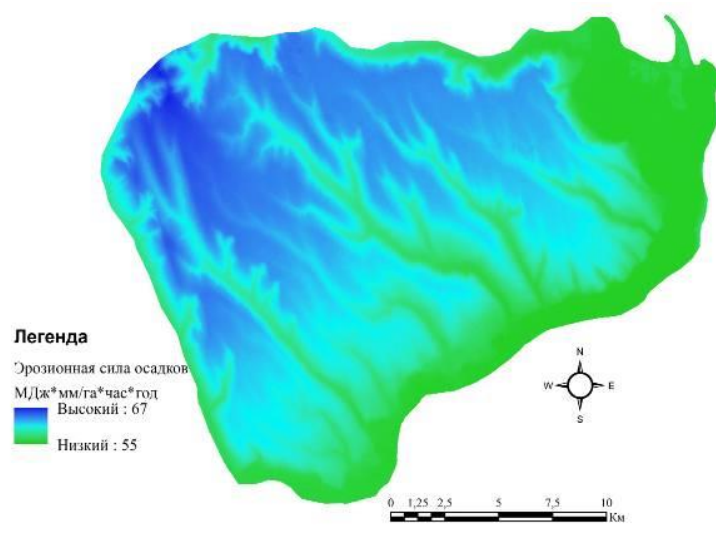

Puc. 4. Эрозионная сила осадков междуречья Ботна-Бык

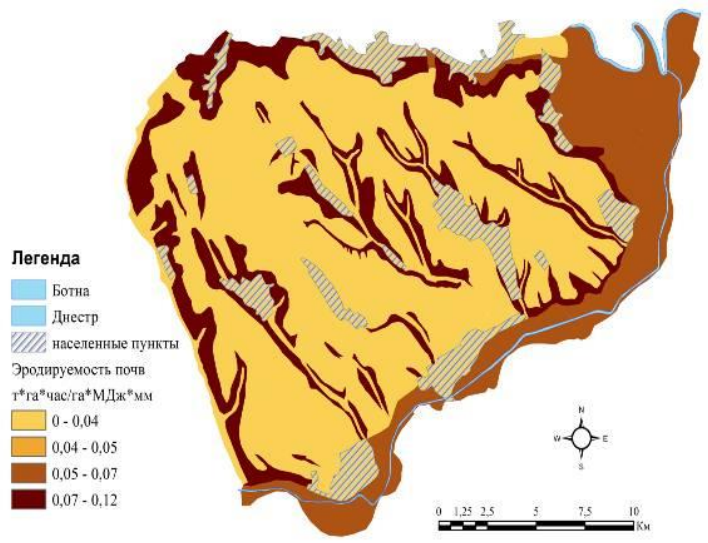

Рuc. 5. Эродируемость почв междуречья Ботна-Бык

Расчет эрозионной силы осадков проводился по среднемесячным данным основных метеорологических величин [9]. При картографировании учитывалась дифференциация количества осадков в соответствии с их высотной зависимостью, выведенной для МССР [7]. Эродируемость почв определена по уравнению RUSLE на основе их гранулометрического состава.

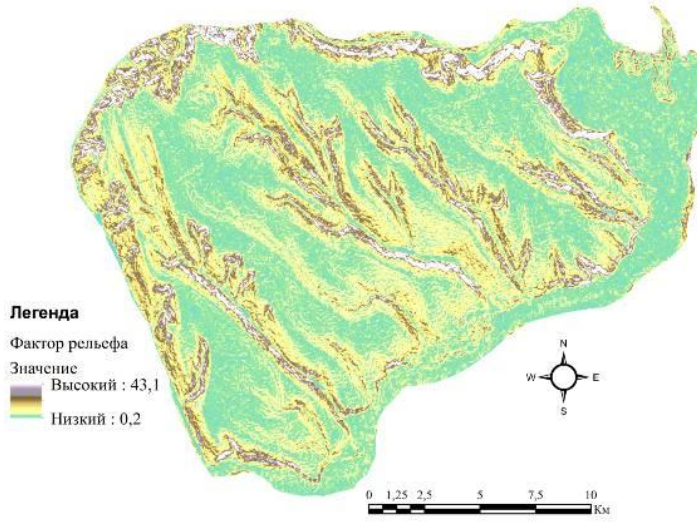

Рuc. 6. Значение рельефной функции на территории междуречья Ботна-Бык

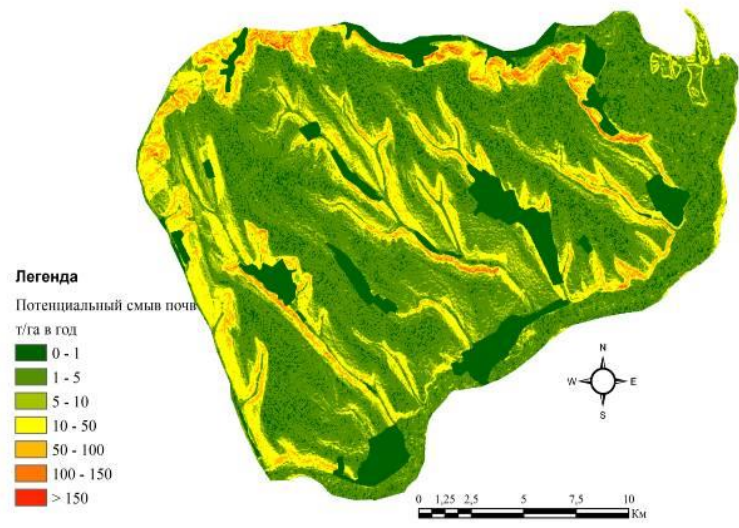

Puc. 7. Потенциальный смыв почв на территории междуречья Ботна-Бык

В условиях расчлененного рельефа междуречья Ботна-Бык обособляются (и через морфологическую структуру, и функционально) каскадные ландшафтно-геохимические системы, сопряженные потоками вещества и энергии, которые на уровне подтипов могут 
быть названы элювиальными, элювиальными слабого транзита, транзитными, элювиальногидроморфными, транзитно-гидроморфными и гидроморфными ландшафтными полосами.

При анализе пространственной картины распределения потенциальной длительности расходования почвы (рис. 8) выделяются ареалы линейной протяженности, которые корреспондируются с ориентацией изогипс и формируют ландшафтные полосы как операционные единицы для земледелия с контурно-мелиоративной организацией агроландшафтов.

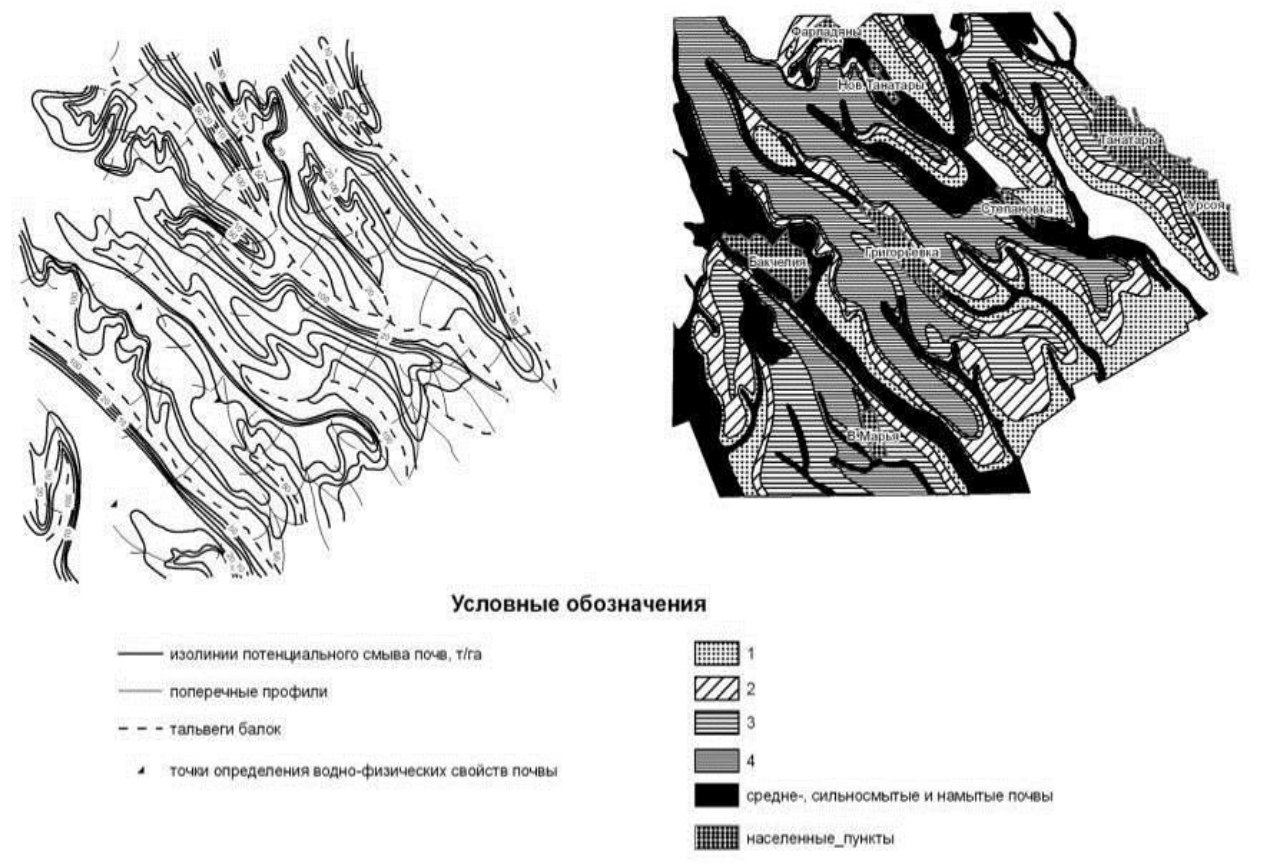

Рuc. 8. Распределение потенциальной длительности расходования почвы (годы) при постоянной среднемноголетней величине смыва на территории междуречья Ботна-Бык.

Длительность использования почвенного ресурса: 1 - менее 200 лет; 2 - 200-500 лет;

$$
3 \text { - 50о-6оо лет; } 4 \text { - 6оо и более лет }
$$

Пространственная картина распределения показателя потенциальной длительности расходования почвы (Т) позволяет определить территории для двух типов экологической реабилитации деградированных земель и/или занимающих позиции с наибольшей эрозионной опасностью ( $<<200$ лет): 1) конверсии сельскохозяйственных угодий в несельскохозяйственные земли (режим консервации); 2) ренатурационного (почвовосстанавливающего) земледелия.

Особый интерес представляет вопрос воздействия искусственного орошения на противоэрозионную стойкость почв. В этой связи в междуречье Ботна-Бык проведены полевые исследования в районе с. Урсоая, с. Танатары, пос. Фарладены и с. Григорьевка. Опыты по искусственному дождеванию проводили в июне-сентябре 1988 г (табл. 1).

В таблице приняты следующие условные обозначения: К - коэффициент структурности [38]; К ветроустойчивости почв); $\mathrm{K}_{\mathrm{A}}$ - коэффициент микроагрегированности; $\mathrm{d}$ средневзвешенный диаметр водопрочных агрегатов, мм; $\mathrm{k}_{0}$ - интенсивность впитывания, мм/мин; $\rho_{о}-$ мутность потока, г/л; $\mathrm{R}_{0}$ - расход наносов (смываемость почвы), г/см. 


\section{Физико-химические свойства почв и их противоэрозионная устойчивость на площадках искусственного дождевания (Молдова, Каушанский район, июнь-сентябрь 1988 г.)}

\begin{tabular}{|c|c|c|c|c|c|c|c|c|c|c|c|c|c|c|c|c|}
\hline \multirow[t]{2}{*}{$\begin{array}{l}\text { Расположение } \\
\text { площадок }\end{array}$} & \multirow[t]{2}{*}{ Агрофон } & \multirow[t]{2}{*}{$\begin{array}{c}\text { Мощность } \\
\mathrm{A}+\mathrm{AB}, \mathrm{cm}\end{array}$} & \multicolumn{2}{|c|}{ Содержание, \% } & \multicolumn{2}{|c|}{$\begin{array}{c}\text { Поглощенные } \\
\text { основания, мг- } \\
\text { экв на } 100 \text { г }\end{array}$} & \multirow[t]{2}{*}{$\begin{array}{l}\mathrm{pH} \\
\text { вод. }\end{array}$} & \multirow[t]{2}{*}{ K } & \multirow[t]{2}{*}{ S } & \multirow[t]{2}{*}{ Ka } & \multirow[t]{2}{*}{$\mathrm{d}$} & \multirow[t]{2}{*}{$\begin{array}{l}\text { Mec } \\
\text { яцы }\end{array}$} & \multirow[t]{2}{*}{ ko } & \multirow[t]{2}{*}{$\rho_{0}$} & \multirow[t]{2}{*}{ Ro } & \multirow[t]{2}{*}{ Ke } \\
\hline & & & гумуса & $\mathrm{CaCO}_{3}$ & $\mathrm{Ca}$ & $\mathrm{Mg}$ & & & & & & & & & & \\
\hline \multicolumn{17}{|c|}{ Чернозем карбонатный тяжелосуглинистый слабосмытый (неорошаемый) } \\
\hline $\begin{array}{l}\text { Приводораз- } \\
\text { дельный } \\
\text { скдон б. } \\
\text { Урсоая }\end{array}$ & кукуруза & $x^{2}$ & 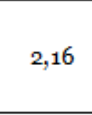 & 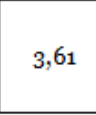 & 21,8 & +2 & 7,75 & 4,3 & 44,3 & 0,42 & 0,30 & $\begin{array}{l}\text { VI } \\
\text { VII }\end{array}$ & $\begin{array}{l}0,50 \\
0,66\end{array}$ & $\begin{array}{c}6,95 \\
10,20\end{array}$ & $\begin{array}{l}0,24 \\
0,38\end{array}$ & $\begin{array}{l}67,9 \\
61,4\end{array}$ \\
\hline \multicolumn{17}{|c|}{ Чернозем карбонатный тяжелосуглинистый слабосмытый (орошаемый) } \\
\hline Там же & кукуруза & 90 & 2,33 & 3,09 & 22,4 & 2,8 & 7,70 & 6,7 & 56,0 & 0,38 & 0,45 & $\begin{array}{l}\text { VI } \\
\text { VII } \\
\text { IX }\end{array}$ & $\begin{array}{l}0,58 \\
0,70 \\
0,18 \\
\end{array}$ & $\begin{array}{c}4,84 \\
16,65 \\
6,91 \\
\end{array}$ & $\begin{array}{l}0,24 \\
1,04 \\
0,19 \\
\end{array}$ & $\begin{array}{l}46,2 \\
65,8\end{array}$ \\
\hline \multicolumn{17}{|c|}{ Чернозем карбонатный тяжелосуглинистый сильносмытый (орошаемый) } \\
\hline Там же & $\begin{array}{l}\text { яр, ячмень с } \\
\text { подсевом } \\
\text { люцерны }\end{array}$ & 36 & 2,04 & 8,58 & 21,2 & 8,4 & 7,75 & 12,3 & 64,0 & 0,43 & 0,55 & $\begin{array}{l}\text { VI } \\
\text { VII }\end{array}$ & $\begin{array}{l}0,60 \\
0,18\end{array}$ & $\begin{array}{l}3,87 \\
7,54\end{array}$ & $\begin{array}{l}0,16 \\
0,43\end{array}$ & $\begin{array}{l}67,4 \\
63,3\end{array}$ \\
\hline \multicolumn{17}{|c|}{ Чернозем карбонатный тяжелосуглинистый (неорошаемый) } \\
\hline $\begin{array}{l}\text { Водораздел } \\
\text { междуречья } \\
\text { Ботна-Бык }\end{array}$ & кукуруза & 120 & 3,02 & 3,61 & 24,4 & 7,2 & 7,65 & 8,3 & 54,6 & 0,44 & 0,88 & $\begin{array}{l}\text { VI } \\
\text { VII }\end{array}$ & $\begin{array}{l}0,31 \\
0,74\end{array}$ & $\begin{array}{c}6,75 \\
18,95\end{array}$ & $\begin{array}{l}0,17 \\
0,59\end{array}$ & $\begin{array}{l}64.2 \\
66.9\end{array}$ \\
\hline \multicolumn{17}{|c|}{ Чернозем карбонатный тяжелосуглинистый (орошаемый) } \\
\hline Там же & картофель & 120 & 2,65 & 2,57 & 25,4 & 4,8 & 7,65 & 7,9 & 56,3 & 0,43 & 0,54 & $\begin{array}{l}\text { VI } \\
\text { VII } \\
\text { IX }\end{array}$ & $\begin{array}{l}0,20 \\
0,30 \\
0,40\end{array}$ & $\begin{array}{c}3,00 \\
19,49 \\
8,30\end{array}$ & $\begin{array}{l}0,24 \\
1,08 \\
0,22 \\
\end{array}$ & $\begin{array}{l}27,4 \\
53,0\end{array}$ \\
\hline
\end{tabular}

Согласно таблице 1, средняя величина смываемости почвы для несмытых карбонатных черноземов составляет 0,21 г/см, для слабосмытых - 0,32 г/см, а для среднесмытых - 0,41 г/см. Сопоставление результатов смываемости почв, определенных Г.И. Швебсом [39] и данными таблицы 1 позволяют сделать вывод, что ее значения за 20 лет увеличились в 1,5 раза для несмытых, в 2 раза - для слабосмытых и среднесмытых.

Таким образом, увеличение интенсификации производства, использование тяжелой техники и применение орошения вызывают уменышение противоэрозионной стойкости почв на территории междуречья Ботна-Бык.

В связи с вышеуказанным, на части территории, сильно пораженной овражной эрозией, следует предусмотреть эколого-реставрационные мероприятия, нацеленные на создание буферных зон или коридоров экологической сети разного уровня, что будет способствовать сохранению биологического разнообразия [40]. Ландшафтные полосы в пределах склоновых местоположений могут быть обоснованы и в результате агроландшафтного картографирования, но количественная оценка процессов формирования-разрушения почвенного профиля, а также составление серии карт микроклиматических неоднородностей (прежде всего, тепло- и влагообеспеченности) с легендами по количественным градациям, уже успешно реализованные с помощью ГИС-технологий для агроэкологической типизации земель, в целом дают более прецизионные решения.

\section{Заключение}

Для обеспечения ландшафтной адаптации ирригации, уменьшения интенсивности расходования почвы, сохранения и расширенного воспроизводства плодородия земель, устойчивости ландшафтов, экономии пресной воды следует переходить к внутрипочвенной импульсной континуально-дискретной парадигме ирригации [41]. Принципиальная ее новизна состоит в том, что открывается возможность поддерживать в почве термодинамический потенциал воды в диапазоне от -0,1 МПа до -0,4 МПа за счет ее подачи внутрь почвы дискретными импульсами. Это позволяет избежать избыточного переувлажнения, сосредоточенных непроизводительных преференсных потоков воды из почвы, обеспечить потребление воды растениями в комфортном диапазоне устьичного регулирования расхода воды при органогенезе [42], опереться на внутрипочвенное роторное фрезерование почвы, утилизацию вещества при фертигации, эффективно использовать возможности гидрогелей [43]. При имеющейся водности источников орошения возможная площадь ирригации может быть многократно больше за счет меньшего расхода пресной воды. 
Комплексное применение методов биогеосистемотехники, адаптивно-ландшафтных подходов к организации землепользования в условиях активного проявления эрозионных процессов обеспечат новые возможности в урегулировании пространственного распределения оценок потенциальной длительности расходования почвы и ландшафтных полос как операционных единиц контурно-мелиоративной организации агроландшафтов, в обеспечении условий для экологической реабилитации деградированных земель в режиме консервации или ренатурации, в повышении эффекта от эколого-реставрационных мероприятий, и создании условия для сохранения биологического разнообразия. Будет обеспечена востребованность агроландшафтного картографирования, ГИС-технологий для прецизионных решений агроэкологической типизации земель.

Исследование выполнено при финансовой поддержке РФФИ в рамках научного проекта № 16-35-50009.

\section{Примечания}

1. Boboc N., Miţul E., Sîrodoev Gh. Единицы рельефа. Масштаб 1: 1500 ооо. Кишинев: Институт экологии и географии АНМ, 2006. 120 с.

2. Билинкис Г.М., Друмя А.В., Дубиновский В.Д., Покатилов В.П. Геоморфология Молдавии. Кишинев: Штиинца, 1978. 188 с.

3. Билинкис Г.М., Буткачук П.Д., Дубиновский В.Д., Покатилов В.П., Чебану Е.Ф., Гуйван П.Е., Ефимова З.Г., Зимовец И.Г. Геоморфологическая карта МССР. Масштаб 1: 200 ооо. Кишинев: Институт геофизики и геологии АН МССР, 1985. 112 с.

4. Мунтян А.Н., Захаров Д.С. Применение геоинформационных технологий для дифференциации генетических типов рельефа долинно-речных комплексов (на примере нижнего Днестра) // Научные ведомости Белгородского государственного университета. Серия Естественные науки. 2014. № 10. С. 166-173.

5. Chiobotaru V., Ivanovittchi C., Constantinov I., Zagarovski V., Ceban P., Ţâganok V., Krupenikov Ig., Andrieş S., Donos T., Kuharuk E., Marinescu C., Revenco E., Ursu A., Jiugău G., Burlacu I., Ungureanu V., Sugaeva T. Buleten de monitoring ecopedologic (pedoerozional) ediţia a treia: red. resp. S. Andrieş, resp. de ediţie D. Balteanschi. Chişinau: Institutul de Ştiinţifice şi Proiectări Tehnologice pentru Pedologie, Agrochimie şi ameliorarea Solurilor «N. Dimo», 1996. 85 p.

6. Билинкис Г.М. Неотектоника Молдавии и смежных районов Украины. Кишинев: Штиинца, 1971. $152 \mathrm{c}$.

7. Крупеников И.А., Урсу А.Ф. Почвы Молдавии. Т. 2. Кишинев: Штиинца, 1985. 240 с.

8. Коробов Р., Тромбицкий И., Сыродоев Г., Андреев А. Уязвимость к изменению климата: Молдавская часть бассейна Днестра: Монография междунар. ассоц. хранителей реки Eco-Tiras. Кишинев: Б.И., 2014. 336 с.

9. Справочник по климату CCCP, вып. 11, ч. IV влажность воздуха, атмосферные осадки, снежный покров; под ред. Г.Ф. Лассе. Л.: Гидрометеорологическое изд-во, 1968. 127 с.

10. Сластихин В.В. Вопросы мелиорации склонов Молдавии / В.В. Сластихин. Кишинев: «Картя Молдовеняскэ», 1964. 212 с.

11. Сластихин В.В., Гаврилица А.О. Воздействие искусственного дождевания и атмосферных осадков на поверхность водосбора // Гидрология малых водосборов. Кишинев: Штиинца, 1978 - С. 19-36.

12. Лисецкий Ф., Сыродоев Г., Голеусов П., Марциневская Л., Нарожняя А. Климатическая обусловленность формирования зональных почв Молдовы // Descrierea CIP a Camerei Naţionale a Cărţii Universitatea Agrară de Stat din Moldova. Lucrări ştiinţifice: [in vol.] / Univ. Agrară de Stat din Moldova, Fac. de Cadastru şi Drept; red.-şef: Gh. Cimpoieş. Chişinău: Centrul editorial UASM. Vol. 33: Cadastru şi drept / col. red. : T. Coşuleanu [et al.]. 2013. P. 76-79.

13. Кольвенко В.В., Ершов Л.В. Комплексная оценка климатических изменений в Приднестровье второй половины XX века - начала XXI века // Геоэкологические и биоэкологические проблемы Северного Причерноморья: Мат. V Междунар. науч.-практ. конф. Тирасполь, 15 ноября 2014 г. Тирасполь: Изд-во Приднестр. ун-та. 2014. С. 134-137.

14. Концепция региональной стратегии адаптации к изменению климата. Приднестровье / Общественная организация Экоспектр. Бендеры: Полиграфист, 2012. 136 с.

15. Гуманюк А.В., Пара Н.П., Погребняк А.П. Влияние факторов интенсификации земледелия на плодородие почв. Тирасполь: Литера, 2010. 216 с. 
16. Кирилюк В.П., Боаге Л.В., Шалагина Н.Г. Агрофизические свойства чернозема выщелоченного и их изменение под влиянием орошения днестровской водой // Современное состояние и перспективы инновационного развития сельского хозяйства: Мат. межд. науч.-практ. конф., посвященной 85-летию со дня основания Научноисследовательского института сельского хозяйства 16-17 нояб. 2015 г. Тирасполь: Eco-Tiras. 2015. №2. C. $482-487$.

17. Боаге Л.В. Результаты исследования влияния орошения днестровской водой на основные физико-химические свойства чернозема выщелоченного // Современное состояние и перспективы инновационного развития сельского хозяйства: Мат. межд. науч. практ. конф., посвященной 85-летию со дня основания Научно-исследовательского института сельского хозяйства 16-17 нояб. 2015 г. Тирасполь: Eco-Tiras. 2015. C. 425-428.

18. Калиниченко В.П., Минкина Т.М., Сковпень А.Н., Ендовицкий А.П., Ильина Л.П., Болдырев А.А., Рыхлик А.Э., Ященко С.А., Ермаков С.А. Обоснование и пути реализации внутрипочвенной импульсной континуально-дискретной парадигмы ирригации // Научный журнал Российского НИИ проблем мелиорации. 2012. № 3(о7). С. 186-198.

19. Калиниченко В.П., Безуглова О.С., Солнцева Н.Г., Сковпень А.Н., Черненко В.В., Ильина Л.П., Болдырев А.А., Шевченко Д.В., Скворцов Д.А. Неблагоприятное влияние орошения на почву и возможности и перспективы применения внутрипочвенной импульсной континуально-дискретной парадигмы ирригации // Научный журнал Российского НИИ проблем мелиорации. 2012. № 2(06). С. 38-49.

20. Калиниченко В.П. Биогеосистемотехника как гносеологическая основа управления экосистемами // Живые и биокосные системы. 2012. Вып. 1. http://www.jbks.ru/archive/issue1/article-3.

21. Калиниченко В.П., Шаршак В.К., Миронченко С.Ф., Черненко В.В., Ладан Е.П., Генев Е.Д., Илларионов В.В., Удалов А.В., Удалов В.В., Киппель Е.В. Изменение свойств почв солонцового комплекса через 30 лет после мелиоративных обработок // Почвоведение. 2014. № 4. C. 490-506.

22. Kalinichenko V.P., and Starcev V.F. Recycling of Poultry Litter by Method of Biogeosystem Technique // International Journal of Environmental Problems. 2015. Vol 1. C. 17-48.

23. Бобченко В.И. Сочетание орошаемого и богарного земледелия // Мелиорация и водное хозяйство. 1998. № 5. С. 5-8.

24. Андреева Т.П., Стратинская Э.Н. Циклическое орошение - способ сохранения плодородия орошаемых земель // Пути повышения эффективности орошаемого земледелия. ФГНУ РосНИИПМ. Новочеркасск. 2009. Вып. 41. С. 61-68.

25. Ясониди О.Е. Капельное орошение. Новочеркасск: Изд-во Рост. ун-та, 2011. 322 с.

26. Воеводина Л.А. Влияние переполивов при капельном орошении на мелиоративное состояние земель // Пути повышения эффективности орошаемого земледелия: сб. ст. ФГНУ РосНИИПМ. Новочеркасск: Геликон. 2011. Вып. 45. С. 49-56.

27. Калиниченко В.П., Минкин М.Б. Трансформация структуры почвенного покрова при ирригации // Почвоведение. 1993. №1. С. 70-76.

28. Калиниченко В.П., Минкина Т.М., Безуглова О.С., Зармаев А.А., Романов О.В., Ким В.Ч.-Д. Концепция внутрипочвенной дискретной импульсной ирригации // Природообустройство. 2013. № 2. С. 6-11.

29. Wiß F., Stacke T., and S. Hagemann. Statistical analysis of simulated global soil moisture and its memory in an ensemble of CMIP 5 general circulation models // Geophysical Research Abstracts. EGU General Assembly. Vienna. 2014. Vol. 16.

30. Агальцева Н.А., Болгов М.В., Спекторман Т.Ю., Трубецкова М.Д., Чуб В.Е. Оценка гидрологических характеристик в бассейне Амударьи в условиях изменения климата // Метеорология и гидрология. 2011. № 10. С. 58-69.

31. Carlos O., Guldan S., Fernald A., Tidwell V., Elias E., Gutierrez K., and M. Borman. Surface water and shallow groundwater interactions in semiarid agro-ecosystems of the western USA // Geophysical Research Abstracts. EGU General Assembly. Vienna. 2014. Vol. 16.

32. Швебс Г.И. Контурное земледелие. Одесса: Маяк, 1985. 56 с.

33. Лисецкий Ф.Н., Белов В.В. Принципы рационального использования почвенного ресурса в районах активного проявления эрозионных процессов // Тез. докл. III съезда 
почвоведов и агрохимиков Украинской ССР. Мелиорация и охрана почв. Харьков: УНИИПА. 1990. С. $185-188$.

34. Лисецкий Ф.Н., Павлюк Я.В., Самофалова О.М. Основные параметрические характеристики сельхозугодий. Свидетельство о государственной регистрации базы данных № 2015620296 от 17.02.2015 г. Дата публикации 20.03.2015 // Программы для ЭВМ, базы данных, топологии интегральных микросхем. 2015. №3. С. 95.

35. Foster G.R., Weesies G.A., Renard K.G., Porter J.P., and Yoder D.C. A Guide to Conservation Planning with the Revised Soil Loss Equation (RUSLE). Agriculture Handbook 703. U.S. Department of Agriculture, 1997. 385 p.

36. Лисецкий Ф.Н., Голеусов П.В., Чепелев О.А. Развитие черноземов ДнестровскоПрутского междуречья в голоцене // Почвоведение. 2013. № 5. С. 540-555.

37. Крупеников И.А. Черноземы Молдавии. Кишинев: Картя Молдовеняскэ, 1967. 427 с.

38. Ревут И.Б. Физика почвы. - Л.: Колос, 1972. 366 с.

39. Швебс Г.И. Формирование водной эрозии стока и их оценка (на примере Украины и Молдавии). - Л: Гидрометеоиздат, 1974. $184 \mathrm{c.}$

40. Германюк Д.Д., Лисецкий Ф.Н., Сыродоев Г.Н. Овраги Кахульской равнины // Buletin Ştiinţific al Muzeului Naţional de Etnografie şi Istorie Naturală a Moldovei. 2007. Vol. 6(19). P. 176-181.

41. Kalinichenko V.P. Patent RU № 2386243 C1. Method of intra-soil pulse discrete irrigation. IPC A01G 25/06 (2006.01) A01S 23/02 (2006.01). Patentee Kalinichenko V.P. Application number 2009102490 on 16.01.09. Published on 20.04.2010. Bull. Number 11.

42. Шеин Е.В. Математические физически обоснованные модели в почвоведении: история развития, современное состояние проблемы и перспективы (аналитический обзор) // Почвоведение. 2015. № 7. С. 816-823.

43. Okolelova A.A., Rachimova N.A., Egorova G.S., Kasterina N.G., Zaikina V. N. Influence of Hydrogels on Productivity of Light-brown Soils // International Journal of Environmental Problem. 2015. Vol. 2. P. 117-135.

\section{References}

1. Boboc N., Miţul E., and Sîrodoev Gh. Edinicy rel'efa. Masshtab 1: 1500 ooo. Kishinev: Institut jekologii i geografii ANM, 2006. $120 \mathrm{p}$.

2. Bilinkis G.M., Drumja A.V., Dubinovskij V.D., and Pokatilov V.P. Geomorfologija Moldavii. Kishinev: Shtiinca, 1978. 188 p.

3. Bilinkis G.M., Butkachuk P.D., Dubinovskij V.D., Pokatilov V.P., Chebanu E.F., Gujvan P.E., Efimova Z.G., and Zimovec I.G. Geomorfologicheskaja karta MSSR. Masshtab 1: 200 ooo. Kishinev: Institut geofiziki i geologii AN MSSR, 1985. $112 \mathrm{p}$.

4. Muntjan A.N., and Zaharov D.S. Primenenie geoinformacionnyh tehnologij dlja differenciacii geneticheskih tipov rel'efa dolinno-rechnyh kompleksov (na primere nizhnego Dnestra) // Nauchnye vedomosti Belgorodskogo gosudarstvennogo universiteta. Serija Estestvennye nauki. 2014. № 10. P. 166-173.

5. Chiobotaru V., Ivanovittchi C., Constantinov I., Zagarovski V., Ceban P., Ţâganok V., Krupenikov Ig., Andrieş S., Donos T., Kuharuk E., Marinescu C., Revenco E., Ursu A., Jiugău G., Burlacu I., Ungureanu V., and Sugaeva T. Buleten de monitoring ecopedologic (pedoerozional) ediţia a treia: red. resp. S. Andrieş, resp. de ediţie D. Balteanschi. Chişinau: Institutul de Ştiinţifice şi Proiectări Tehnologice pentru Pedologie, Agrochimie şi ameliorarea Solurilor «N. Dimo», 1996. $85 \mathrm{p}$.

6. Bilinkis G.M. Neotektonika Moldavii i smezhnyh rajonov Ukrainy. Kishinev: Shtiinca, 1971. $152 \mathrm{p}$.

7. Krupenikov I.A., and Ursu A.F. Pochvy Moldavii. T. 2. Kishinev: Shtiinca, 1985. 240 p.

8. Korobov R., Trombickij I., Syrodoev G., and Andreev A. Ujazvimost' k izmeneniju klimata: Moldavskaja chast' bassejna Dnestra: Monografija mezhdunar. assoc. hranitelej reki EcoTiras. Kishinev: B.I., 2014. 336 p.

9. Spravochnik po klimatu SSSR, vyp. 11, ch. IV vlazhnost' vozduha, atmosfernye osadki, snezhnyj pokrov; pod red. G.F. Lasse. L.: Gidrometeorologicheskoe izd-vo, 1968 - 127 p.

10. Slastihin V.V. Voprosy melioracii sklonov Moldavii / V.V. Slastihin. - Kishinev: «Kartja Moldovenjaskje», $1964-212 \mathrm{p}$. 
11. Slastihin V.V., and Gavrilica A.O. Vozdejchtvie iskusstvennogo dozhdevanija i atmosfernyh osadkov na poverhnost' vodosbora // Gidrologija malyh vodosborov. - Kishinev: Shtiinca, 1978 - P. 19-36.

12. Liseckij F., Syrodoev G., Goleusov P., Marcinevskaja L., and Narozhnjaja A. Klimaticheskaja obuslovlennost' formirovanija zonal'nyh pochv Moldovy // Descrierea CIP a Camerei Naţionale a Cărţii Universitatea Agrară de Stat din Moldova. Lucrări ştiinţifice: [in vol.] / Univ. Agrară de Stat din Moldova, Fac. de Cadastru şi Drept; red.-şef: Gh. Cimpoieş. Chişinău: Centrul editorial UASM. Vol. 33: Cadastru şi drept / col. red. : T. Coşuleanu [et al.]. 2013. P. 76-79.

13. Kol'venko V.V., and Ershov L.V. Kompleksnaja ocenka klimaticheskih izmenenij v Pridnestrov'e vtoroj poloviny XX veka - nachala XXI veka // Geojekologicheskie i biojekologicheskie problemy Severnogo Prichernomor'ja: Mat. V Mezhdunar. nauch.-prakt. konf. Tiraspol', 15 nojabrja 2014 g. Tiraspol': Izd-vo Pridnestr. un-ta. 2014. P. 134-137.

14. Koncepcija regional'noj strategii adaptacii $\mathrm{k}$ izmeneniju klimata. Pridnestrov'e / Obshhestvennaja organizacija «Jekospektr». Bendery: Poligrafist, 2012. 136 p.

15. Gumanjuk A.V., Para N.P., and Pogrebnjak A.P. Vlijanie faktorov intensifikacii zemledelija na plodorodie pochv. Tiraspol': Litera, 2010. 216 p.

16. Kiriljuk V.P., Boage L.V., and Shalagina N.G. Agrofizicheskie svojstva chernozema vyshhelochennogo i ih izmenenie pod vlijaniem oroshenija dnestrovskoj vodoj // Sovremennoe sostojanie i perspektivy innovacionnogo razvitija sel'skogo hozjajstva: Mat. mezhd. nauch. - prakt. konf., posvjashhennoj 85-letiju so dnja osnovanija Nauchno-issledovatel'skogo instituta sel'skogo hozjajstva 16-17 nojab. 2015 g. Tiraspol': Eco-Tiras. 2015. №2. P. 482-487.

17. Boage L.V. Rezul'taty issledovanija vlijanija oroshenija dnestrovskoj vodoj na osnovnye fiziko-himicheskie svojstva chernozema vyshhelochennogo // Sovremennoe sostojanie i perspektivy innovacionnogo razvitija sel'skogo hozjajstva: Mat. mezhd. nauch. - prakt. konf., posvjashhennoj 85-letiju so dnja osnovanija Nauchno-issledovatel'skogo instituta sel'skogo hozjajstva 16-17 nojab. 2015 g. Tiraspol': Eco-Tiras. 2015. P. 425-428.

18. Kalinichenko V.P., Minkina T.M., Skovpen' A.N., Endovickij A.P., Il'ina L.P., Boldyrev A.A., Ryhlik A.Je., Jashhenko S.A., and Ermakov S.A. Obosnovanie i puti realizacii vnutripochvennoj impul'snoj kontinual'no-diskretnoj paradigmy irrigacii // Nauchnyj zhurnal Rossijskogo NII problem melioracii. 2012. № 3(07). P. 186-198.

19. Kalinichenko V.P., Bezuglova O.S., Solnceva N.G., Skovpen' A.N., Chernenko V.V., Il'ina L.P., Boldyrev A.A., Shevchenko D.V., and Skvorcov D.A. Neblagoprijatnoe vlijanie oroshenija na pochvu i vozmozhnosti i perspektivy primenenija vnutripochvennoj impul'snoj kontinual'nodiskretnoj paradigmy irrigacii // Nauchnyj zhurnal Rossijskogo NII problem melioracii. 2012. № 2(06). P. 38-49.

20. Kalinichenko V.P. Biogeosistemotehnika kak gnoseologicheskaja osnova upravlenija jekosistemami // Zhivye i biokosnye sistemy. 2012. Vyp. 1. http://www.jbks.ru/archive/issue$1 /$ article-3.

21. Kalinichenko V.P., Sharshak V.K., Mironchenko S.F., Chernenko V.V., Ladan E.P., Genev E.D., Illarionov V.V., Udalov A.V., Udalov V.V., and Kippel' E.V. Izmenenie svojstv pochv soloncovogo kompleksa cherez 30 let posle meliorativnyh obrabotok // Pochvovedenie. 2014. №4. P. 490-506.

22. Kalinichenko V. P., and Starcev V. F. Recycling of Poultry Litter by Method of Biogeosystem Technique // International Journal of Environmental Problems. 2015. Vol 1. P. 17-48.

23. Bobchenko V.I. Sochetanie oroshaemogo i bogarnogo zemledelija // Melioracija i vodnoe hozjajstvo. 1998. № 5. P. 5-8.

24. Andreeva T.P., and Stratinskaja Je.N. Ciklicheskoe oroshenie - sposob sohranenija plodorodija oroshaemyh zemel' // Puti povyshenija jeffektivnosti oroshaemogo zemledelija. FGNU RosNIIPM. Novocherkassk. 2009. Vyp. 41. P. 61-68.

25. Jasonidi O.E. Kapel'noe oroshenie. Novocherkassk: Izd-vo Rost. un-ta, 2011. 322 p.

26. Voevodina L.A. Vlijanie perepolivov pri kapel'nom oroshenii na meliorativnoe sostojanie zemel' // Puti povyshenija jeffektivnosti oroshaemogo zemledelija: sb. st. FGNU «RosNIIPM». Novocherkassk: Gelikon. 2011. Vyp. 45. P. 49-56.

27. Kalinichenko V.P., and Minkin M.B. Transformacija struktury pochvennogo pokrova pri irrigacii // Pochvovedenie. 1993. №1. P. 70-76. 
28. Kalinichenko V.P., Minkina T.M., Bezuglova O.S., Zarmaev A.A., Romanov O.V., and Kim V.Ch.-D. Koncepcija vnutripochvennoj diskretnoj impul'snoj irrigacii // Prirodoobustrojstvo. 2013. № 2. P. 6-11.

29. Wiß Felix, Stacke Tobias, and Hagemann Stefan, Statistical analysis of simulated global soil moisture and its memory in an ensemble of CMIP 5 general circulation models // Geophysical Research Abstracts. EGU General Assembly. Vienna. 2014. Vol. 16.

30. Agal'ceva N.A., Bolgov M.V., Spektorman T.Ju., Trubeckova M.D., and Chub V.E. Ocenka gidrologicheskih harakteristik v bassejne Amudar'i v uslovijah izmenenija klimata // Meteorologija i gidrologija. 2011. № 10. P. 58-69.

31. Carlos Ochoa, Guldan Steve, Fernald Alexander, Tidwell Vince, Elias Emile, Gutierrez Karina, and Borman Mike. Surface water and shallow groundwater interactions in semiarid agroecosystems of the western USA // Geophysical Research Abstracts. EGU General Assembly. Vienna. 2014. Vol. 16.

32. Shvebs G.I. Konturnoe zemledelie. Odessa: Majak, 1985. 56 p.

33. Liseckij F.N., and Belov V.V. Principy racional'nogo ispol'zovanija pochvennogo resursa $\mathrm{v}$ rajonah aktivnogo projavlenija jerozionnyh processov // Tez. dokl. III s\#ezda pochvovedov i agrohimikov Ukrainskoj SSR. Melioracija i ohrana pochv. Har'kov: UNIIPA. 1990. P. 185-188.

34. Liseckij F.N., Pavljuk Ja.V., and Samofalova O.M. Osnovnye parametricheskie harakteristiki sel'hozugodij. Svidetel'stvo o gosudarstvennoj registracii bazy dannyh № 2015620296 ot 17.02.2015 g. Data publikacii 20.03.2015 // Programmy dlja JeVM, bazy dannyh, topologii integral'nyh mikroshem. 2015. №3. P. 95.

35. Foster G.R., Weesies G.A., Renard K.G., Porter J.P., and Yoder D.C. A Guide to Conservation Planning with the Revised Soil Loss Equation (RUSLE). Agriculture Handbook 703. U.S. Department of Agriculture, 1997. 385 p.

36. Liseckij F.N., Goleusov P.V., and Chepelev O.A. Razvitie chernozemov DnestrovskoPrutskogo mezhdurech'ja v golocene // Pochvovedenie. 2013. № 5. P. 540-555.

37. Krupenikov I.A. Chernozemy Moldavii. Kishinev: Kartja Moldovenjaskje, 1967. 427 p.

38. Revut I.B. Fizika pochvy. L.: Kolos, 1972. 366 p.

39. Shvebs G.I. Formirovanie vodnoj jerozii stoka i ih ocenka (na primere Ukrainy i Moldavii). L: «Gidrometeoizdat», 1974. 184 p.

40. Germanjuk D.D., Liseckij F.N., and Syrodoev G.N. Ovragi Kahul'skoj ravniny // Buletin Ştiinţific al Muzeului Naţional de Etnografie şi Istorie Naturală a Moldovei. 2007. Vol. 6(19). P. 176-181.

41. Kalinichenko V.P. Patent RU № 2386243 C1. Method of intra-soil pulse discrete irrigation. IPC A01G 25/o6 (2006.01) A01S 23/02 (2006.01). Patentee Kalinichenko V.P. Application number 2009102490 on 16.01.09. Published on 20.04.2010. Bull. Number 11.

42. Shein E.V. Matematicheskie fizicheski obosnovannye modeli v pochvovedenii: istorija razvitija, sovremennoe sostojanie problemy i perspektivy (analiticheskij obzor) // Pochvovedenie. 2015. № 7. P. 816-823.

43. Okolelova A.A., Rachimova N.A., Egorova G.S., Kasterina N.G., and Zaikina V.N. Influence of Hydrogels on Productivity of Light-brown Soils // International Journal of Environmental Problem. 2015. Vol. 2. P. 117-135. 
УДК 631.485

\title{
Оценка длительности расходования почвы в условиях активного развития эрозионных процессов (на примере Нижнебыковской равнины)
}

\author{
1 Федор Н. Лисецкий \\ 2 Александр Н. Мунтян \\ 3 Ксения В. Жолумская
}

1, 3 Белгородский государственный национальный исследовательский университет, Белгород, Российская Федерация

308015 Белгород, ул. Победы, 85

2 Республиканский научно-исследовательский институт экологии и природных ресурсов, Бендеры, Республика Молдова

1 д.г.н., профессор

E-mail: liset@bsu.edu.ru

${ }^{2}$ Ведущий научный сотрудник

E-mail: piter504@mail.ru

3 E-mail: zholumskaya@list.ru

Аннотация. Исследованы предпосылки формирования почвозащитных систем земледелия и перспектив развития оросительной мелиорации в условиях активного проявления водной эрозии почв (на примере сильно расчлененной центральной части Республики Молдова). Установлено, что за последние 20 лет из-за интенсификации сельскохозяйственного производства, использования тяжелой техники и применения орошения величина смываемости почв увеличились в 1,5-2 раза. Показано, что в пределах склоновой подсистемы агроландшафтов единицы позиционно-динамического типа имеют вид довольно узких ландшафтных полос. Их границы можно обосновать не только методами ландшафтного картографирования, но и при помощи комплексного показателя потенциальной длительности расходования почвы, который включает оценки запасов почвенных ресурсов и скоростей ресурсоформирующих и почворазрушающих процессов. Этот подход, дополняемый применением серии карт микроклиматических неоднородностей (прежде всего, тепло- и влагообеспеченности), имеющих количественные градации в легенде, и выполненных с помощью геоинформационных технологий, позволяет провести агроэкологическую типизацию земель и определить наиболее рациональные местоположения для осуществления эколого-реставрационных мероприятий.

В результате комплексного применения методов биогеосистемотехники, адаптивноландшафтных подходов к организации землепользования в условиях активного проявления эрозионных процессов появляются новые возможности для регулирования расходования почвы в границах ландшафтных полос как операционных единиц контурно-мелиоративной организации агроландшафтов, для обеспечения условий экологической реабилитации деградированных земель в режиме консервации или ренатурации, а также создания условий для сохранения биологического разнообразия.

Ключевые слова: эрозия почв, формирование почвы, орошение земель, противоэрозионные мелиорации. 